\title{
The Information-Seeking Habits of Architecture Faculty
}

\section{Lucy Campbell}

\begin{abstract}
This study examines results from a survey of architecture faculty across the United States investigating information-seeking behavior and perceptions of library services. Faculty were asked to rank information sources they used for research, teaching, and creativity within their discipline. Sources were ranked similarly across these activities, suggesting broad and eclectic interests. While Internet resources and books were important across the board, e-books were ranked low. As an information source, librarians were also perceived to have less value than peers or even students. Librarians should consider ways to make libraries experiential and inspiring to add value and demonstrate continued relevance in an ever-expanding information field.
\end{abstract}

\section{Introduction}

A fundamental question facing academic libraries is how to maintain relevance. Attracting faculty by supporting research interests and expanding the intellectual and cultural life of institutions are recognized methods. Assessing the needs of faculty is a key step toward library innovation: for example, designing new approaches to information retrieval and improving user services. However, knowing what faculty need, what they desire, and how they discover it, is challenging. Architecture is a particularly tricky field because of its multidisciplinary nature. This research seeks to clarify those needs for librarians and information professionals working closely with architecture faculty and facilitate the provision of quality services that speak directly to the discipline.

While multiple studies have explored the information literacy competencies of architecture students, little work has specifically addressed faculty interests. ${ }^{1}$ Due to the multifaceted nature of architectural research, it is a distinctive field warranting additional scrutiny. This study addresses this gap by clarifying the perceived role of the librarian in the information-gathering process and ascertaining information-seeking behavior patterns of architecture faculty for research, teaching, and design inspiration. The results should be of interest to anyone looking to enhance information services and facilitate scholarly architectural research, while improving the perceived value of library resources for architecture faculty.

\section{Literature Review}

Information behavior is a relatively new but growing research field. A recent review found 615 studies were published between 2009 and 2013. ${ }^{2}$ Researchers have investi-

Lucy Campbell is a Librarian at the New School of Architecture E Design; e-mail: lcampbell@newschoolarch.edu. (C2017 Lucy Campbell, Attribution-NonCommercial (http://creativecommons.org/licenses/ by-nc/4.0/) CC BY-NC. 
gated the information needs of faculty and students at academic institutions, as well as professionals within the workplace. Some studies focus on specific disciplines, while others address general populations. While some researchers have studied the information needs of architecture students, very little attention has been paid to how faculty in the discipline look for and use information. ${ }^{3}$ The value of studying information-seeking behaviors of faculty within specific disciplines is widely acknowledged, and numerous studies have sought to establish best practices. Matsumori looked at the information needs of faculty in music schools. ${ }^{4}$ Hart surveyed faculty in a comprehensive college. ${ }^{5}$ In 2008, Mulen, Murthy, and Teague looked at the information needs of research faculty. ${ }^{6}$ Reed and Tanner have examined the information needs of fine arts faculty, ${ }^{7}$ while Rupp-Serrano and Robbins surveyed education faculty in $2013 .{ }^{8}$ Since 2000, the triennial Ithaka S+R US Faculty Survey has also sought to establish changing scholarly perceptions of academic libraries. ${ }^{9}$ However, there is a gap in research addressing the specific information needs of architecture faculty.

Previous research has discussed how the information-related behavior of design practitioners differs from other academic disciplines. While the sciences are heavily dependent on recent journal literature and the humanities are book-focused, the creative disciplines are unique. A 2001 study of faculty in art, music, theater, and dance emphasized the need for broad collections, highly specialized resources, and multiple formats. ${ }^{10}$ As in the fine arts, architecture faculty may have diverse, highly individualistic information needs related to practice, research, and teaching. Many schools hire for the unique position of Professor in Practice and explicitly require continued work within the professional realm. ${ }^{11}$ The skills and expertise acquired in nonacademic careers are essential to contemporary architectural education. For some architecture faculty, then, the pressure to design may be greater than the need to publish.

Architecture is an interdisciplinary field occupying a bridge among the arts, the sciences, and the humanities. Although grounded in the design process, the nature of architectural research requires scholars to draw from social sciences such as psychology, sciences such as climatology, and deeply technical fields such as engineering and mathematics. Jeanne M. Brown has discussed the need for architecture to relate to and speak the language of other disciplines. ${ }^{12}$ It places high value on team-based interdisciplinarity, in which experts bring together many different types of skills, and exploratory interdisciplinarity, in which research from exterior fields is incorporated.

Makri and Warwick's close study of information-seeking behavior among graduate architecture students concluded that creativity was a unique aspect in the use of information tools. ${ }^{13}$ Images were of particular importance, as were interactions with colleagues. Similarly, a 2013 study concluded that faculty place great emphasis on images for presentations, papers, and course-content preparation. ${ }^{14}$ A study of education faculty conducted the same year found that e-books were more important than print books. ${ }^{15}$ In 2015, Lo and Chu found that art and design students remain heavy users of printed materials and physical libraries, while also using Internet resources and social networks. ${ }^{16}$ This indicates that, at least for creative individuals, online information sources are complementing rather than replacing those already in existence. Like students, faculty now operate in a hybrid environment of print and electronic resources. However, the question of how new formats have altered information behavior for architecture faculty, and which formats they value most, remains unanswered. Some examples of information habits specific to architecture include frequent jumping between visual and text-based resources, reviewing current building codes, selecting materials, conducting site analyses, and researching typologies and case studies. The degree to which these specialized methods affect information use in terms of formats and attitudes is not clear. 
Much research has focused on the attitudes of students and faculty toward academic libraries. There is a general consensus that faculty continue to see their value. Recently, Library Journal and Cengage partnered to conduct a major study of faculty attitudes toward library services. Most respondents saw the library as vital to student instruction and faculty research but were less enthusiastic about collection development or support for research grants. ${ }^{17}$ A 2013 study found that 88 percent of education faculty felt library research was important to their field. ${ }^{18}$ Teague, Mullen, and Murphy explored faculty attitudes toward support for research and scholarship, concluding that material resources were deemed critical. ${ }^{19}$ Zanin-Yost found that, while faculty of art history may be frequent library users, their studio peers were less so, suggesting practicing creatives see less value in libraries. ${ }^{20}$ By contrast, a 2011 study of the information behavior of artists found them to be heavy users of the Internet, social networks, print resources, and physical library space..$^{21}$ How architecture faculty compare is an interesting question, considering their analogous interests. In 1996, Klos asserted there was "architecture faculty in every university in the United States who avoid using the library or discussing a research problem with the librarian." 22 Ten years on, this study seeks to ascertain if this problem still exists.

The concept of information as inspiration is gaining popularity and changing academic architecture libraries. Brown has argued that, rather than providing products, libraries now provide experiences that generate ideas. ${ }^{23}$ Some examples she gives include thematic displays, panel discussions exploring interdisciplinary topics, and emphasis on interactions in design studios. Lo and Chu noted the importance of information as inspiration in the design disciplines in their recent study, ${ }^{24}$ and Payne has suggested there is a disconnect between traditional academic research and the reality of design scholarship. ${ }^{25}$ By determining information-seeking habits and attitudes, this study hopes to address this disconnect for architecture faculty occupying the intersection between creative space and academic research.

\section{Methodology}

This study originated from conversations with faculty at the library desk, who bemoaned the apparent divide between faculty who do and do not frequent the library. The goal was to ascertain the information-seeking behavior of architecture faculty and thereby determine some of the factors influencing use. Surveys are recognized as the preferred and predominant method for research in information behavior. ${ }^{26}$ They allow the collection of objective, anonymous information that can be compared and crosstabulated to recognize meaningful relationships. Online surveys are more convenient and less intimidating than in-person surveys, questionnaires, or interviews. As this study looked at use of and attitudes toward information, an online survey was chosen as the most appropriate tool. The cloud-based online survey development software SurveyMonkey was selected, as the author was both familiar with the software and able to easily manipulate data for analysis.

The first half of the survey sought to establish the information-seeking habits of faculty, while the second half focused on attitudes toward information sources. The survey was designed to solicit responses from all architecture faculty regardless of rank or institution type. It included fifteen questions and was designed to be completed in five minutes or less. The first eight questions on background and library use asked respondents to select from preset options. The next four questions required respondents to rate resources on a scale, one being unimportant and five being crucial. The final three questions sought to ascertain opinions toward library services. Although not required, all questions provided opportunities for comments and open-ended responses. Researchers in information behavior have reported 
confusion among respondents when distinguishing Internet resources, e-books, journal databases, and online resources. ${ }^{27}$ To provide clarity, Internet resources were specifically defined as freely available and discoverable via a search engine (such as Google). A pilot survey was shared with four architecture faculty for review and feedback prior to distribution.

The survey was distributed using a variety of methods. It was posted on listservs, including the Association of Architecture School Librarians (AASL) and the Art Librarians Society of North America (ARLIS/NA). Librarians were asked to share with their architecture faculty via e-mail and inform the author how many faculty received the survey at their institutions. The author solicited responses through direct e-mail and wrote an article about the study that was published online by the Association of Collegiate Schools of Architecture (ACSA). The survey was open for six weeks, during which time a conservative estimate of 606 recipients received the survey, and 99 responded, giving a response rate of 16 percent. In 2014, the National Bureau of Labor Statistics estimated there were 6,130 people teaching architecture in colleges, universities, and professional schools across the United States. ${ }^{28}$ Therefore, a total of 10 percent of the national population received the survey. Although it represents a small percentage of the total population, responses represented a range of faculty, by position within their institutions (see figure 1), years of teaching experience (see figure 2 ), and institution type (such as research, private, state, for-profit). In fact, the range of positions reflected was wider than anticipated, with nearly 20 percent reporting a position not listed. These included Assistant Professor, Professor Emeritus, Researcher, Academic Chair, and Lecturer.

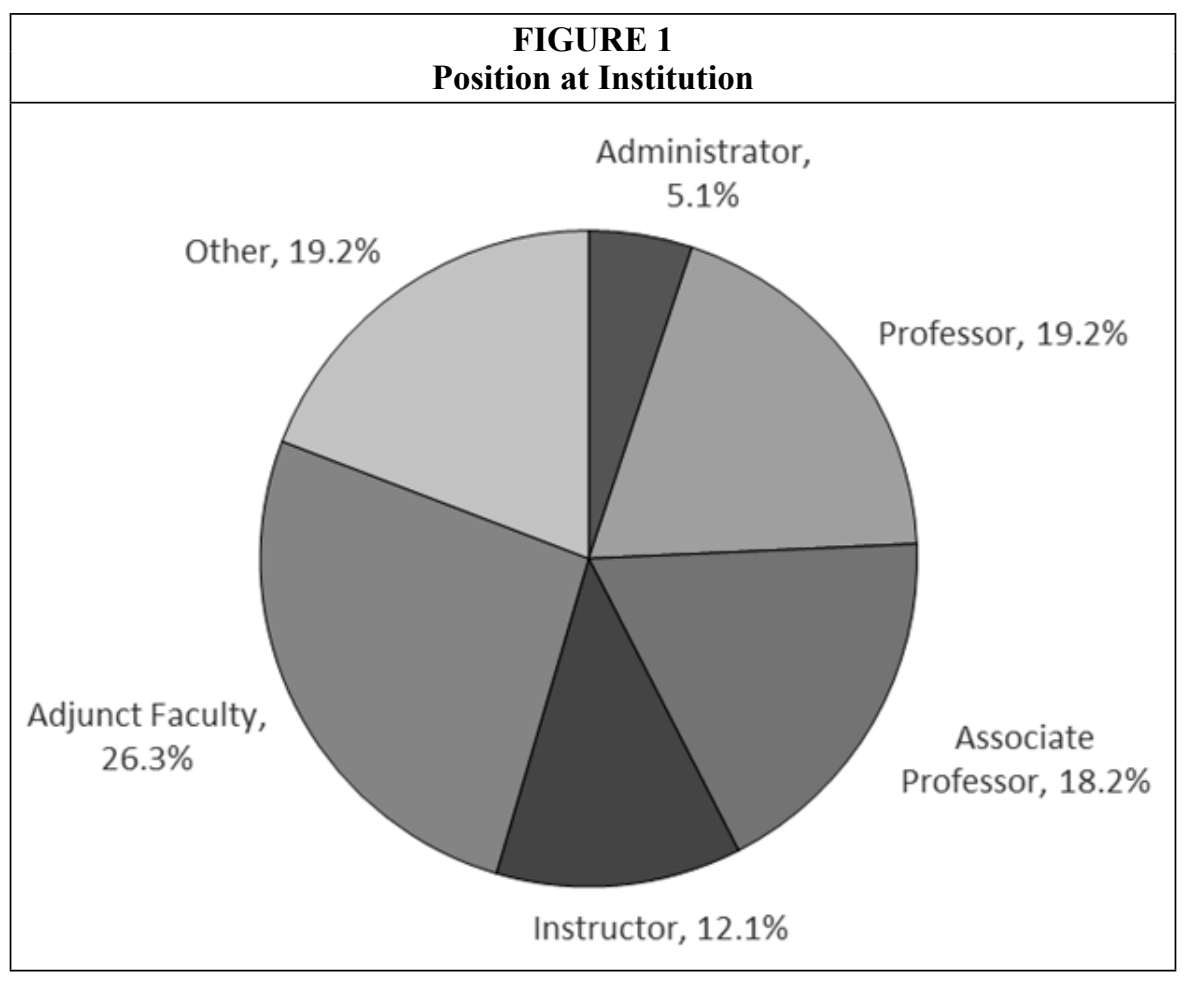




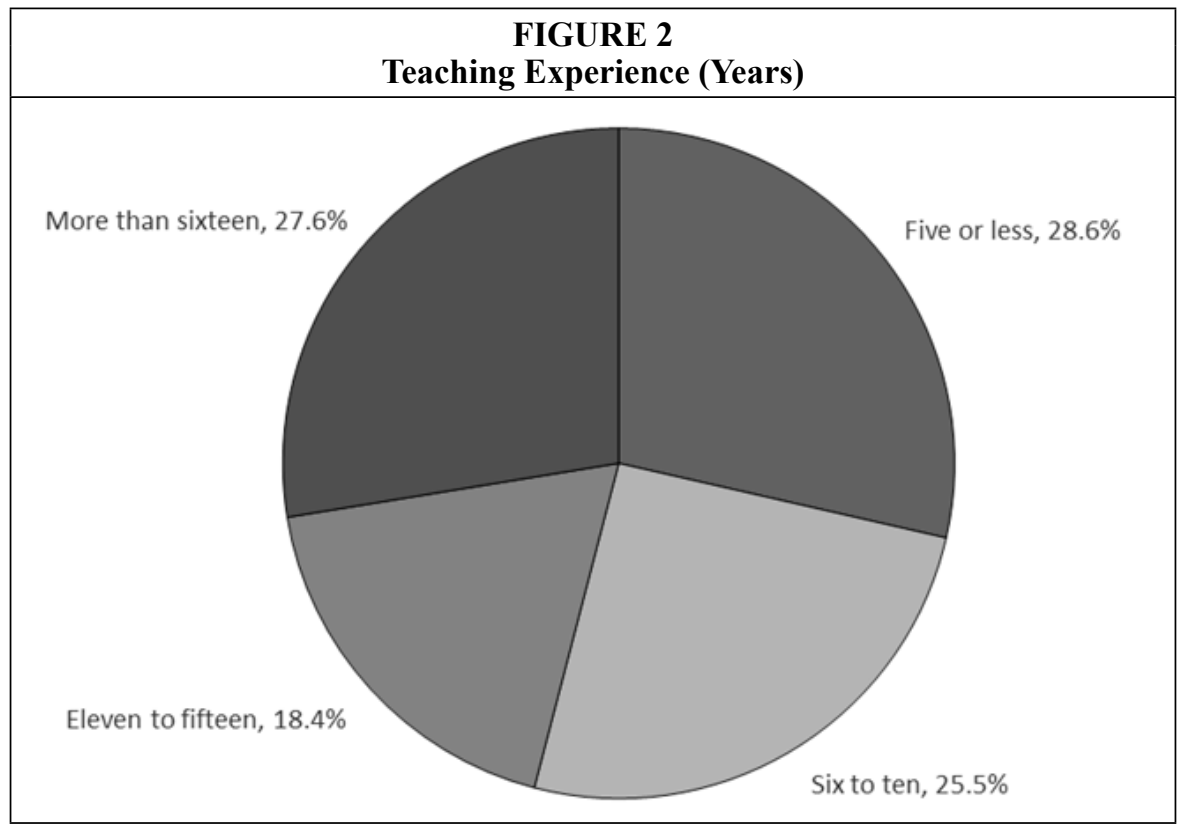

\section{Findings}

\section{Information Use}

This survey indicates there is widespread consensus that information resources remain vital to the practice and pedagogy of architecture. However, it also suggests the differences among perceived value of various information sources for research, teaching, and inspiration are negligible. In all cases, e-books, discussion lists, and conversations with librarians were ranked low, while personal books, Internet resources, and

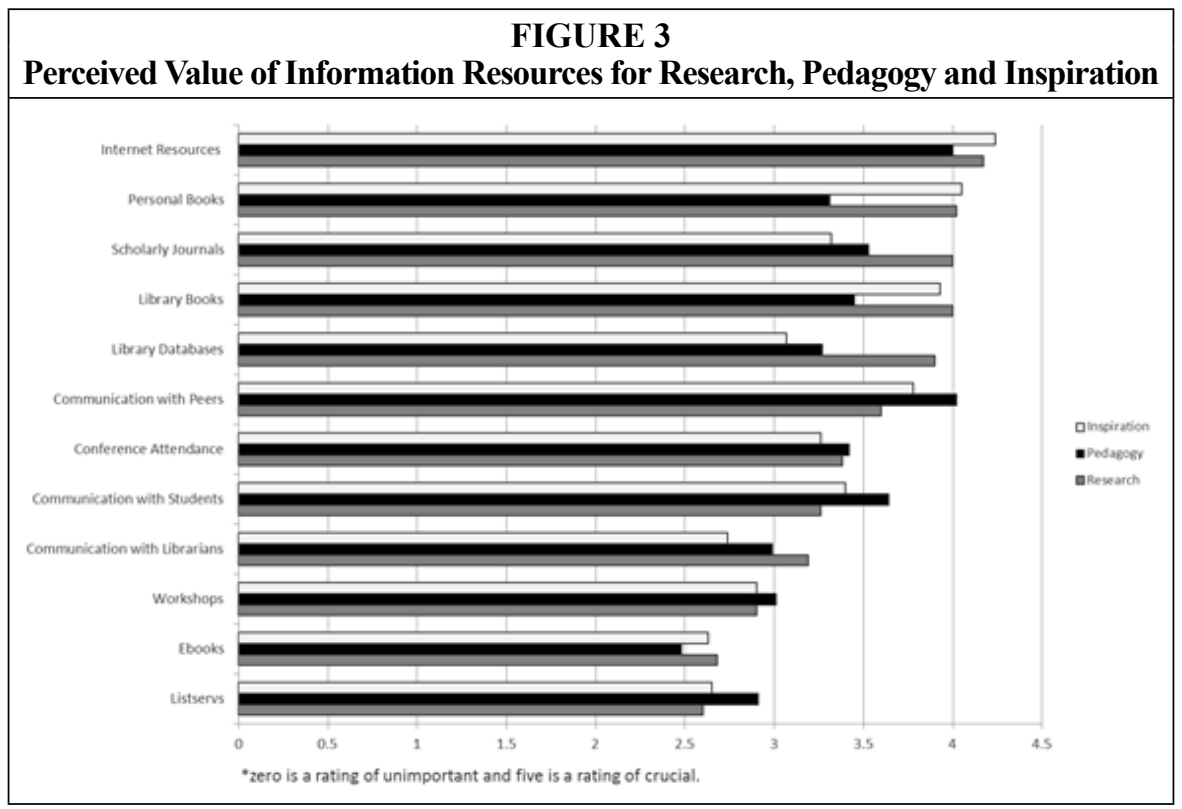


conversations with peers were highly ranked. Library books were used for all three activities, while scholarly journals were less important for inspiration (see figure 3). Internet resources and personal libraries were the most important sources for both research and creative inspiration, while personal communication with peers was the most important resource for architectural education. Across the board, e-books were ranked comparatively low, with an average score of 2.6 out of 5 .

Personal book collections were particularly popular, with 93 percent of respondents reporting they had a private library for academic purposes. Faculty reported purchasing an average of 16 books per year, although numbers ranged widely from 2 to 100. Surprisingly, faculty with more experience were less likely to collect books; only faculty with more than 16 years of teaching experience reported they did not have a personal library.

Despite ranking low in perceived importance, 62 percent of respondents had personal subscriptions to scholarly periodicals. The average number of subscriptions for those choosing to subscribe was 3.5 per person. While administrators generally viewed scholarly journals as more valuable, there was no significant variation in perceived value of other research resources by position at institution.

All image types were ranked highly for importance to the discipline (see figure 4). Photographs and architectural plans were deemed particularly critical, with half of respondents viewing these as crucial resources. Art such as sketches and watercolors were deemed the least important, behind statistical graphs and infographics.

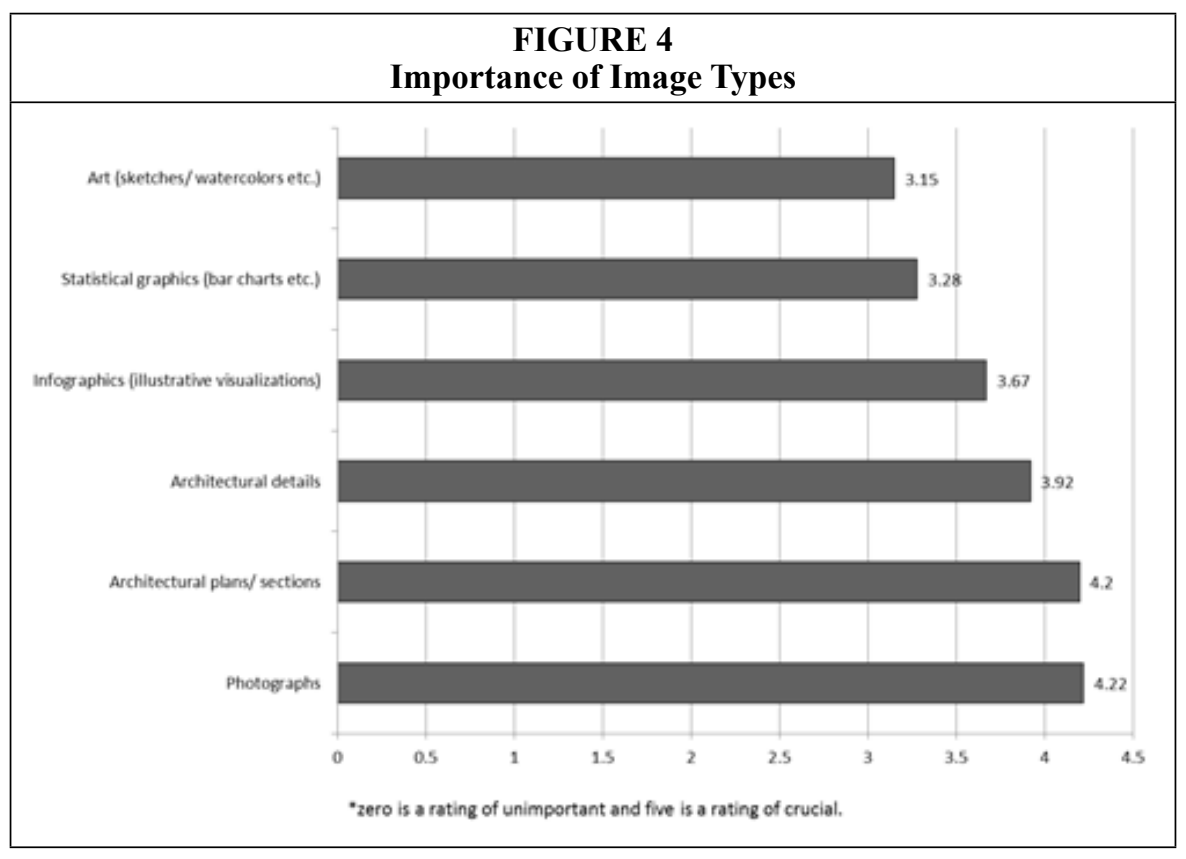

\section{Library Use}

Overall, 27 percent of respondents reported visiting their library at least once per week (see figure 5). The most frequent visitors were faculty with 6-10 years of teaching experience. Nearly half of this group (46\%) visited the library at their institutions weekly. Adjunct faculty were the only group that included individuals who never visited the library. Regardless of experience or position, the majority of respondents (78\%) used 
their institutional library for private research. Other activities such as reading, holding meetings, and using amenities (including printers, computers, scanners, and the like) were pursued by less than half of respondents (see figure 6). Additional reasons given for visiting the library included (in order of frequency) instruction, placing books on reserve, and talking with a librarian.
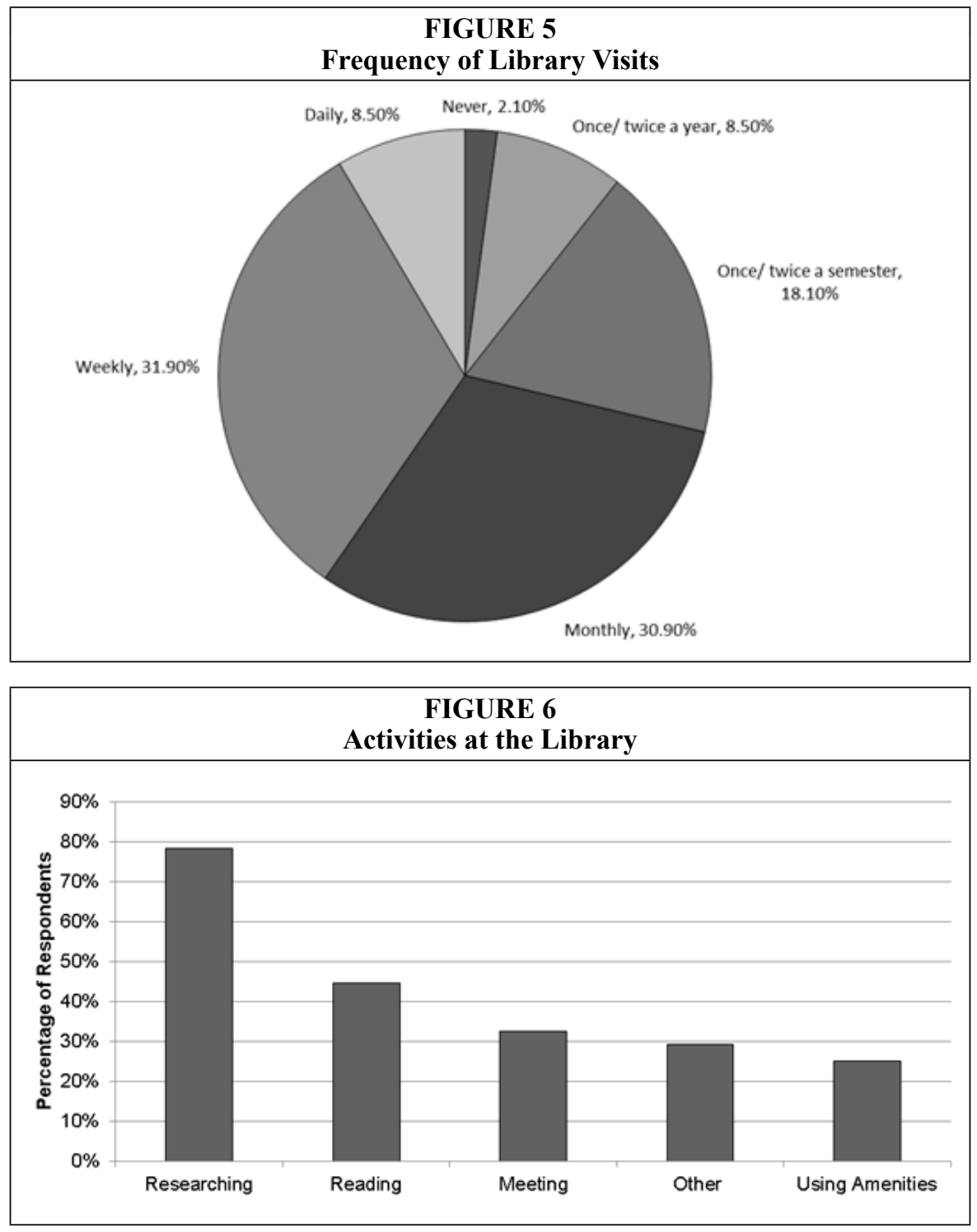

Only half the respondents reported designing a built or unbuilt architectural project in the last five years, although one commented about having consulted on built projects. Successfully obtaining a research grant was the only activity fewer faculty engaged in. By contrast, more than 80 percent had presented at a conference, and nearly two-thirds had published an article or book (see figure 7). However, for adjunct faculty this trend 
was reversed, with a higher percentage designing built or unbuilt projects and just 41 percent reporting academic publication (see figure 8). Interdisciplinary collaboration was also common, at 68 percent.
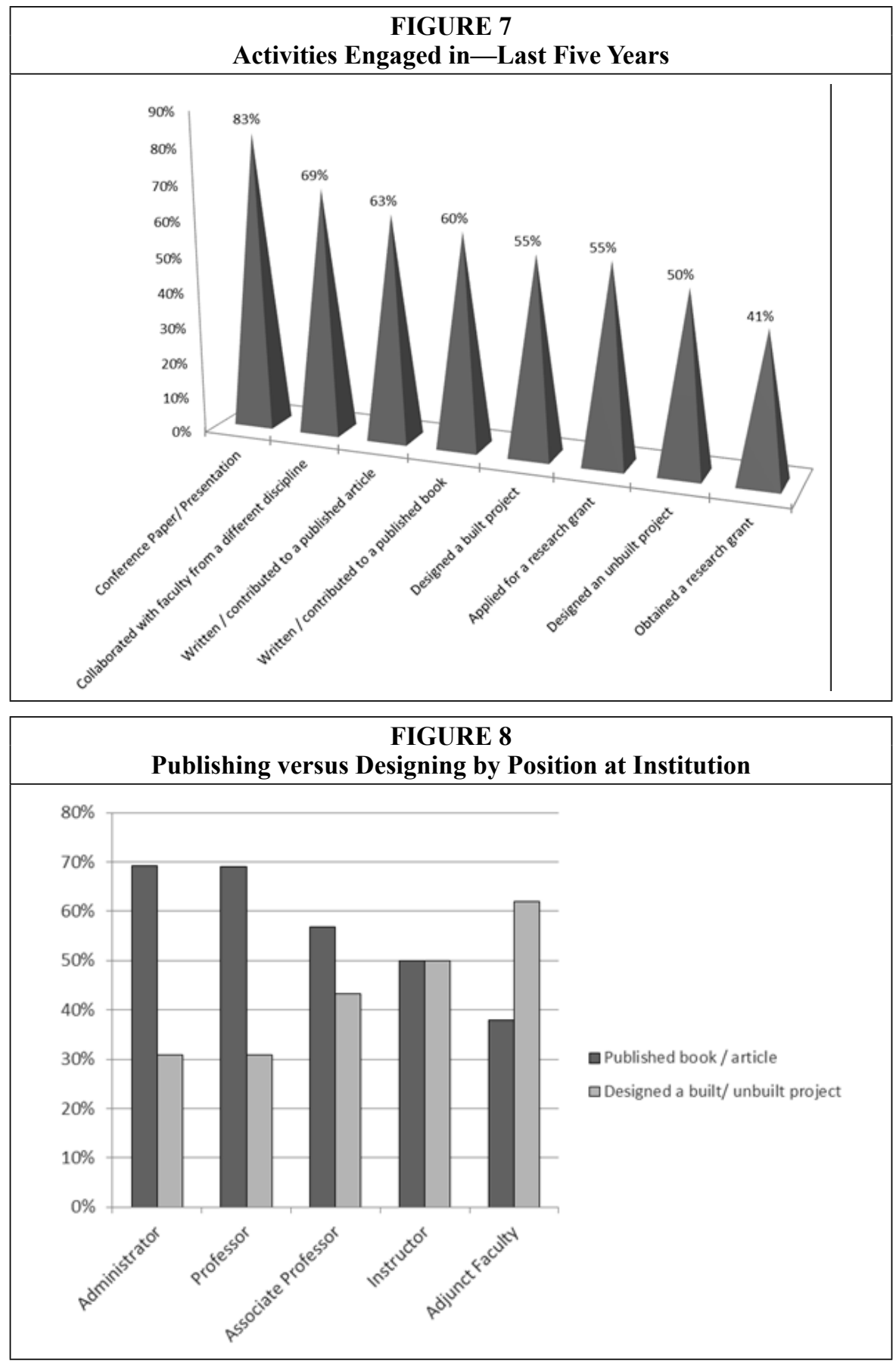


\section{Frequency of Information Use}

While writing and presenting a conference paper was the most commonly reported academic activity (83\%) it was also one of the least frequent reasons for seeking information, with the majority reporting they engaged in it just once or twice per semester. Daily information seeking focused around inspiration and keeping up with trends in the discipline (see figure 9). Course preparation was the most common weekly activity, with 53 percent of respondents seeking information every week. The greatest range was evident in writing and research for publication and professional development. Architecture faculty show a wide range in the frequency with which they carry out these information activities.

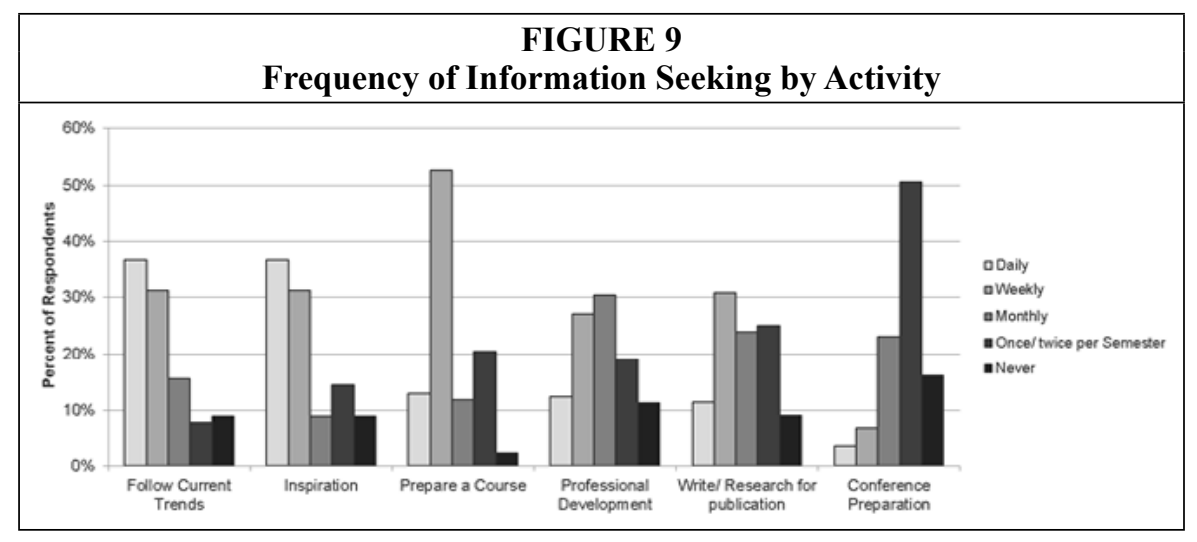

\section{Attitudes toward Libraries}

Nearly 80 percent of respondents felt they received support from their institutional library, and more than half were satisfied with the services provided. Administrators were far more vocal about the additional services they felt the institutional library should offer, while adjunct faculty were more satisfied despite reporting low library use and less academic support. Overall, no significant correlation was found between demographics and attitudes toward library services. Of the 30 comments received,

\begin{tabular}{|c|c|c|c|c|c|}
\hline \multicolumn{6}{|c|}{$\begin{array}{c}\text { TABLE } 1 \\
\text { Attitudes towards Library Resources }\end{array}$} \\
\hline & $\begin{array}{l}\text { Strongly } \\
\text { Disagree }\end{array}$ & Disagree & Neutral & Agree & $\begin{array}{c}\text { Strongly } \\
\text { Agree }\end{array}$ \\
\hline $\begin{array}{l}\text { Printed materials are very valuable } \\
\text { to my discipline }\end{array}$ & $\begin{array}{c}\mathbf{0 . 0 0 \%} \\
0\end{array}$ & $\begin{array}{c}\mathbf{0 . 0 0 \%} \\
0\end{array}$ & $\begin{array}{c}5.88 \% \\
5\end{array}$ & $\begin{array}{l}\mathbf{2 8 . 2 4 \%} \\
24\end{array}$ & $\begin{array}{c}\mathbf{6 5 . 8 8 \%} \\
56\end{array}$ \\
\hline $\begin{array}{l}\text { Resources selected and organized } \\
\text { by library staff are more useful than } \\
\text { those that are not }\end{array}$ & $\begin{array}{c}2.35 \% \\
2\end{array}$ & $\begin{array}{c}\mathbf{5 . 8 8} \% \\
5\end{array}$ & $\begin{array}{c}\mathbf{4 0 . 0 0 \%} \\
34\end{array}$ & $\begin{array}{l}\mathbf{3 8 . 8 2} \% \\
33\end{array}$ & $\begin{array}{c}\mathbf{1 2 . 9 4 \%} \\
11\end{array}$ \\
\hline $\begin{array}{l}\text { Internet-based resources do an } \\
\text { adequate job of meeting my search } \\
\text { needs }\end{array}$ & $\begin{array}{c}\mathbf{2 0 . 9 3 \%} \\
18\end{array}$ & $\begin{array}{l}\mathbf{2 5 . 5 8 \%} \\
22\end{array}$ & $\begin{array}{l}\mathbf{2 9 . 0 7 \%} \\
25\end{array}$ & $\begin{array}{c}\mathbf{2 0 . 9 3 \%} \\
18\end{array}$ & $\begin{array}{c}3.49 \% \\
3\end{array}$ \\
\hline $\begin{array}{l}\text { I would be fine with my library } \\
\text { cancelling print journals and making } \\
\text { them available electronically instead }\end{array}$ & $\begin{array}{c}30.23 \% \\
26\end{array}$ & $\begin{array}{l}\mathbf{2 2 . 0 9 \%} \\
19\end{array}$ & $\begin{array}{c}\mathbf{1 7 . 4 4 \%} \\
15\end{array}$ & $\begin{array}{c}\mathbf{1 8 . 6 0 \%} \\
16\end{array}$ & $\begin{array}{c}\mathbf{1 1 . 6 3 \%} \\
10\end{array}$ \\
\hline
\end{tabular}


better electronic resources stood out as the most desired service for one-third of respondents. JSTOR was specifically mentioned by five respondents, as well as Science Direct and ArchGIS. A wide variety of print resources were also identified, including El Croquis, Detail, Log, and MARK. Although applying for and obtaining grants were the least common activities, grant-writing support was explicitly mentioned as a desirable library service in 10 percent (3) of the comments.

Respondents were ambiguous about print journals being replaced with digital access, feeling that online resources alone were adequate for their research needs. Despite this, two-thirds felt that print materials remain important to the discipline (see table 1).

One respondent felt that architecture faculty are "good at using information, but we do not understand how to efficiently organize it to ensure maximum benefit." Another stated it is "impossible for the library to keep current with design standards, which are important to my work," while another shrewdly noted that we need "a longer discussion to define what a library should be."

\section{Attitudes toward Librarians}

Librarians as information sources were generally ranked low. One exception was perceived importance among faculty teaching 6-10 years, who rated librarians highly as an information source for research (3.59 out of 5). The survey showed a certain neutrality toward the role of library staff as organizers and selectors of information sources. Forty percent felt neutral about the expertise a librarian can bring, with one commenting, "Library staff cannot provide the same insights as my informed colleagues [who] are actively part of the architectural discourse." However, positive comments were also offered, including "My architecture librarian was simply invaluable in the recent research and writing of my book" and "We have a subject librarian who is supremely helpful." These statements indicate the continued value of specialized subject knowledge for architecture librarians.

\section{Discussion}

Although a survey was the most appropriate research method, results should be considered in light of social desirability bias. This phenomenon refers to stated opinions that attempt to mask negative attitudes that respondents may be reluctant to reveal. ${ }^{29}$ Despite anonymity, faculty may manipulate answers because they feel they are representatives of their workplace. Although social desirability bias may influence survey results, research methods used were based on tried and tested techniques. We can therefore draw some significance from findings.

In some respects, this survey supports previous research into the information-seeking habits of faculty in creative disciplines. As concluded by Makri and Warwick, interactions with colleagues are key to obtaining new information. ${ }^{30}$ Information needs are varied both in terms of source and material. Despite the proliferation and popularity of online resources, print materials continue to be used simultaneously. This is supported by the Ithaka 2015 survey, which concluded that preference for print resources among humanist scholars has actually increased slightly since $2012 .{ }^{31}$ It also reflects the concept of "obscure sources" for inspiration as discussed by Lo and Chu, who noted that, because inspiration can come from anywhere, the ability of a library to provide information needs is limited by the mediums it can collect. ${ }^{32}$

Faculty are aware of this shortcoming as well, as evidenced by their ambivalence toward library resources and continued willingness to build personal collections of research materials. In 1989, Morton and Price found that faculty purchased an average of 21 books each year. ${ }^{33}$ In 1997, Hart reported a number of 15.8. ${ }^{34}$ The average number among architecture faculty (16) demonstrates continued importance. However, while 
Reed and Tanner's 2011 study of faculty in the creative fields found academics ranked books as the most important information source, ${ }^{35}$ architecture faculty ranked colleagues and online sources more highly. Again, this suggests that architecture faculty are broad and eclectic searchers. The range of additional library services suggested by respondents also indicates that, for some faculty, the library is more than just a collection of books.

Significant contrasts in survey results demonstrate how what we want doesn't always reflect what we need. For example, faculty suggested that libraries should support grant writing, yet they rated it the least important activity. They also felt scholarly journals were the least important resource, yet a majority continue to subscribe to them. Similarly, clear favoritism was expressed for online resources; yet, when asked if print resources were important, over two-thirds strongly agreed.

Architecture faculty desire a wide variety of information resources. However, the reality of expanding options and shrinking budgets means librarians must choose the resources that do the most good for the most patrons while acknowledging the demand for diversity. Providing access to broad yet unique collections and seeking to develop compelling experiences are some best practices to support architecture faculty and their information needs. The seemingly contradictory concept of broad yet unique collections can be achieved by both emphasizing what is special about library holdings and ensuring a solid contemporary architectural collection. Through interdisciplinary connections and unexpected resources, libraries can remain fertile ground for the activities of teaching, research, and creating.

Neutrality toward library staff could indicate a larger problem. Hrycaj and Russo have suggested that lack of commitment to express an opinion may disguise negative opinions faculty are reluctant to share. ${ }^{36}$ Perceived lack of knowledge has damaged attitudes toward librarians within the discipline. To improve perceptions, it is clear that librarians must know their subject. Rentfrow summarizes this need for "librarianscholars prepared and trained by degree programs that require rigorous scholarship." ${ }^{\prime 37}$ She suggests that professional training is the key factor in changing faculty perceptions of what librarians do. For architecture librarians, this means understanding both the creative and scholarly processes. In particular, Rentfrow emphasizes the importance of librarians publishing to demonstrate their intellectual and scholarly contributions, particularly outside the discipline of Library Science. An evolving skill set and a willingness to collaborate beyond the library are characteristics crucial to success as a contemporary information professional. Some tried and tested examples include regular one-on-ones with faculty to gain understanding of their personal research interests, sharing new book lists with faculty interested in growing their personal libraries, increasing electronic access, and being flexible when fashioning library services to unique needs. Libraries can also support faculty by offering a space in which crucial interactions with colleagues can occur.

Compelling experiences may include anything outside the traditional keeper-ofthe-books model. McArthur and Graham have suggested that the principles of userexperience design applied to libraries can improve interactions. ${ }^{38}$ The associated memories and feelings of well-considered spaces encourage patron use. This is particularly relevant for design scholars who have a well-developed appreciation for aesthetics. Norman also emphasizes the importance of behavioral design, or services based on specific needs. ${ }^{39}$ Libraries can begin by identifying the unique and specialized needs of their users; then they can design services to fit those needs. He recommends using focus groups, interviews, and observed patron interactions to identify these needs. Usability is one important aspect of behavioral design. For libraries, this means that patrons should feel comfortable locating and using resources independently. 


\section{Conclusion}

This study looked at information seeking through the very specific lens of architecture faculty within the United States. Yet a range of styles and approaches toward information seeking is represented. Traditional information sources remain important to the discipline, and many faculty continue to subscribe to print journals and purchase physical books. Architectural plans, details, and photographs are the most important image types. When seeking information, faculty are most frequently looking for inspiration or current trends. The more in-depth activity required for writing, or preparing conference presentations, is less regular. Internet resources are perceived as more valuable overall; but, rather than replacing print sources, they are providing additional options. Perceived importance and reported usage do not always correlate, demonstrating inconsistency between wants and needs. The number of faculty designing built or unbuilt projects was lower than anticipated. Generally, we can conclude that adjunct faculty will practice more, while full-time faculty will focus more on research and teaching. While attitudes toward institutional libraries are overwhelmingly positive, and at least one-third of faculty are regular library visitors (once each week), librarians are not viewed as key information resources.

There is no cookie-cutter, one-size-fits-all solution to addressing faculty needs in the architecture library. A library cannot be everything for everyone, but perhaps (as Sheila Klos suggests) we should see the architecture library as less a collection of all necessary information and more a directory, or jumping-off point, from which to gain access and become inspired. ${ }^{40}$

\section{Notes}

1. Patrick Lo and Wilson $\mathrm{Chu}$, "Information for Inspiration: Understanding InformationSeeking Behavior and Library Usage of Students at the Hong Kong Design Institute," Australian Academic \& Research Libraries 46, no. 2 (2015): 101-20.

2. Heidi Julien and Michael O'Brien, "Information Behavior Research: Where Have We Been, Where Are We Going?" Canadian Journal of Information and Library Science 38, no. 4 (2014): 239-50.

3. Hannah Bennett, "Bringing the Studio into the Library: Addressing the Research Needs of Studio Art and Architecture Students," Art Documentation: Journal of the Art Libraries Society of North America 25, no. 1 (2006): 38-42.

4. Donald Mikio Matsumori, The Analysis of the Information Transfer Process among Music School Faculty with Implications for Library Systems and Services Design (Los Angeles: University of Southern California, 1981).

5 Richard L. Hart, "Information Gathering among the Faculty of a Comprehensive College: Formality and Globality," Journal of Academic Librarianship 23, no. 1 (1997): 21.

6. Carol A. Mullen, Uday Murthy, and Greg Teague, "Listening to Those We Serve: Assessing the Research Needs of University Faculty," Journal of Research Administration 39, no. 1 (2008): $10-31$.

7. Bonnie Reed and Donald R. Tanner, "Information Needs and Library Services for the Fine Arts Faculty," Journal of Academic Librarianship 27, no. 3 (2001): 229-33.

8. Karen Rupp-Serrano and Sarah Robbins, "Information-Seeking Habits of Education Faculty," College \& Research Libraries 74, no. 2 (2013): 131-41.

9. Christine Wolff, Alisa B. Rod, and Roger C. Schonfeld, "Ithaka S+R US Faculty Survey 2015," Ithaka S+R (Apr. 4, 2016), available online at http://www.sr.ithaka.org/publications/ithakasr-us-faculty-survey-2015/ [accessed 10 February 2015].

10. Reed and Tanner, "Information Needs and Library Services."

11. AAUP, "Professors of Practice" (Dec. 2006), available online at www.aaup.org/report/ professors-practice [accessed 10 February 2015].

12. Jeanne M. Brown, "Indicators of the Evolution of the Academic Architecture Library," Art Documentation 25, no. 2 (2006): 6-11.

13. Stephann Makri and Claire Warwick, "Information for Inspiration: Understanding Architects' Information Seeking and Use Behaviors to Inform Design," Journal of the American Society for Information Science \& Technology 61, no. 9 (2010): 1745-70, doi:10.1002/asi.21338.

14. Ken Huang and Diane Kelly, "The Daily Image Information Needs and Seeking Behavior 
of Chinese Undergraduate Students," College \& Research Libraries 74, no. 3 (2013): 243-61.

15. Rupp-Serrano and Robbins, "Information-Seeking Habits of Education Faculty," 140.

16. Lo and Chu, "Information for Inspiration," 101-02.

17. Library Research Journal and Gale Cengage Learning, "Bridging the Librarian-Faculty Gap in the Academic Library," e-book (United States: Library Journal, 2015).

18. Rupp-Serrano and Robbins, "Information-Seeking Habits of Education Faculty," 140.

19. Mullen, Murthy, and Teague, "Listening to Those We Serve," 10-31.

20. A. Zanin-Yost, "Liaison for the Visual Arts: Responding to the Needs of Diverse Demands," in The Handbook of Art and Design Librarianship, eds. Paul Glassman and Amanda K. Gluibizzi (United Kingdom: American Library Association, 2010).

21. Helen Mason and Lyn Robinson, "The information-Related Behavior of Emerging Artists and Designers," Journal of Documentation 67 (2011): 159-80.

22. Sheila M. Klos, "Information Literacy for the Next Generation," Journal of Architectural Education 49, no. 3 (1996): 204-06.

23. Brown, "Indicators of the Evolution," 9.

24. Lo and Chu, "Information for Inspiration," 116.

25. Daniel Payne, "Creative Space," in The Handbook of Art and Design Librarianship, eds. Paul

Glassman and Amanda K. Gluibizzi (United Kingdom: American Library Association, 2010).

26. Julien and O'Brien, "Information Behavior Research," 248.

27. Rupp-Serrano and Robbins, "Information-Seeking Habits of Education Faculty," 140.

28. Bureau of Labor Statistics, "Architecture Teachers, Postsecondary" (last modified Mar. 30,

2016), available online at www.bls.gov [accessed 10 February 2015].

29. Paul Hrycaj and Michael Russo, "Reflections on Surveys of Faculty Attitudes toward Collaboration with Librarians," Journal of Academic Librarianship 33, no. 6 (2007): 694.

30. Makri and Warwick, "Information for Inspiration," 1770.

31. Wolff, Rod, and Schonfeld, "Ithaka S+R US Faculty Survey 2015."

32. Lo and $\mathrm{Chu}$, "Information for Inspiration," 116.

33. Herbert Charles Morton and Anne J. Price, The ACLS Survey of Scholars: Final Report of Views on Publications, Computers, and Libraries (Washington, D.C.: Office of Scholarly Communication and Technology, American Council of Learned Societies, 1989).

34. Hart, "Information Gathering among the Faculty of a Comprehensive College," 25.

35. Reed and Tanner, "Information Needs and Library Services," 231.

36. Hrycaj and Russo, "Reflections on Surveys of Faculty Attitudes," 694.

37. Daphne Rentfrow, "Groundskeepers, Gatekeepers and Guides: How to Change Faculty Perceptions of Librarians and Ensure the Future of the Research Library," in No Brief Candle: Reconceiving Libraries for the 21st Century, (Washington, D.C.: Council on Library and Information Resources, 2008).

38. John A. McArthur and Valerie Johnson Graham, "User-Experience Design and Library Spaces: A Pathway to Innovation?" Journal of Library Innovation 6, no. 2 (2015).

39. Donald A. Norman, Emotional Design: Why We Love (or Hate) Everyday Things, 3rd ed. (New York: Basic Books, 2003).

40. Klos, "Information Literacy for the Next Generation," 205. 